\title{
Synthesis, structural investigation and kinetic studies of uranyl(VI) unsymmetrical Schiff base complexes
}

\author{
ZAHRA ASADI ${ }^{\mathrm{a}, *}$, MOZAFFAR ASADI $^{\mathrm{a}}$, AZADE ZEINALI $^{\mathrm{a}}$, \\ MOHAMMAD RANJKESHSHORKAEI ${ }^{\mathrm{a}}$, KARLA FEJFAROVA ${ }^{\mathrm{b}}$, VACLAV EIGNER $^{\mathrm{b}}$, \\ MICHAL DUSEK ${ }^{\mathrm{b}}$ and ALIAKBAR DEHNOKHALAJI ${ }^{\mathrm{c}}$ \\ ${ }^{a}$ Chemistry Department, College of Sciences, Shiraz University, Shiraz 71454, I. R. Iran \\ ${ }^{b}$ Institute of Physics ASCR, v.v.i, Na Slovance 2, 18221 Praha, Czech Republic \\ ${ }^{\mathrm{c}}$ Department of Chemistry, Faculty of Science, Golestan University, Gorgan, Iran \\ e-mail: zasadi@shirazu.ac.ir; zasadi@susc.ac.ir
}

MS received 14 December 2013; revised 27 April 2014; accepted 29 April 2014

\begin{abstract}
Uranyl(VI) complexes with unsymmetrical $\mathrm{N}_{2} \mathrm{O}_{2}$ Schiff base ligands were synthesized and characterized. Their characterization was performed using UV-Vis, ${ }^{1} \mathrm{H}$ NMR, cyclic voltammetry, single-crystal X-ray crystallography, IR, TG and C.H.N. techniques. X-ray crystallography of the complexes show that beside coordination of the tetradentate Schiff base, one DMF molecule is also coordinated. In order to investigate the effect of the substitutional groups of the Schiff base on the oxidation and reduction potentials, we used the cyclic voltammetry method. Electrochemistry of these complexes showed that the presence of electron releasing groups accelerates oxidation of the complexes. The kinetics of thermal decomposition was studied using thermal gravimetric method (TG) and Coats-Redfern equation. According to Coats-Redfern plots, the kinetics of thermal decomposition of the studied complexes is first-order in all stages. Also the kinetics and mechanism of the exchange reaction of the coordinated solvent with tributylphosphine was carried out in solution, using spectrophotometric method. As a result, the second order rate constants at four temperatures and the activation parameters were calculated showing an associative mechanism for all corresponding complexes. It was concluded that the steric and the electronic properties of the complexes influence the reaction rate significantly.
\end{abstract}

Keywords. Uranyl schiff base complexes; kinetic study; X-ray crystallography; kinetics of thermal decomposition; cyclic voltammetry.

\section{Introduction}

Uranium is known in oxidation states III, IV, $\mathrm{V}$ and VI in solution. Uranium (V) is unstable in solution, because of the disproportionation. Therefore, the properties of $\mathrm{U}(\mathrm{V})$ compounds are not well investigated. On the other hand, a large number of studies have been done on the properties of $\mathrm{U}(\mathrm{VI})$ and $\mathrm{U}(\mathrm{IV})$ compounds. ${ }^{1-9}$

The interest in synthesis and characterization of uranyl(VI) Schiff base complexes has an increasing trend. Uranyl tetra-dentate Schiff base complexes have a distorted pentagonal bipyramidal structure with the solvent molecule occupying the fifth equatorial coordination site. The most probable coordination number in the equatorial plane of $\mathrm{U}(\mathrm{VI})$ is 5 or 6 . On this basis, a penta- or hexa-dentate planar ligand should be

\footnotetext{
*For correspondence
}

appropriate to expel any mono-dentate ligand or solvent molecule from the equatorial plane. In the case of $\mathrm{N}_{2} \mathrm{O}_{2}$ tetra-dentate ligands, the bond distances between $\mathrm{U}$ and $\mathrm{N}$ are longer than the $\mathrm{U}-\mathrm{O}$ distances in the equatorial plane and the $\mathrm{U}^{\mathrm{VI}} \mathrm{O}_{2}^{2+}$ moiety is slightly bent. ${ }^{10-20}$ It is worthy to note that the reduction of uranium from $\mathrm{U}(\mathrm{VI})$ to $\mathrm{U}(\mathrm{V})$ weakens $\mathrm{U}=\mathrm{O}$ bond strength and it is an evidence to redox reaction. . $^{21,22}$

In this paper, our interest is focused on the complexes of uranyl with 3-MeOsalbz, 4-MeOsalbz, 5-MeOsalbz and the solvent $\mathrm{MeOH}$ (figure 1). X-ray crystallography and TG revealed that one solvent molecule was coordinated weakly to the uranium centre, in comparison to the Schiff base and trans oxides. Thus, it is interesting to study the kinetics of exchange of this solvent molecule with tributylphosphine and the parameters affecting the rate constants such as the electronic and the steric ones. From this point of view, the effect of substitutional groups on the redox potential of these complexes was studied. 


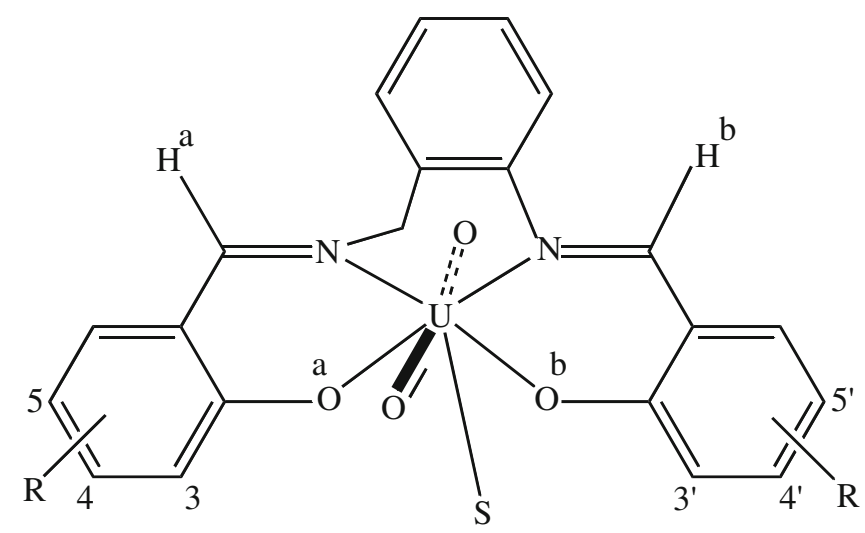

Figure 1. Structural representation of the uranyl(VI) Schiff base complex $\mathrm{R}=\mathrm{OMe}$ and $\mathrm{S}=$ solvent.

\section{Experimental}

\subsection{Chemicals and apparatus}

5-methoxy-2-hydroxysalicylaldehyde, 4-methoxy-2hydroxysalicylaldehyde, 3-methoxy-2-hydroxysalicylaldehyde, 2-aminobenzylamine, uranylacetatedihydrate $\mathrm{UO}_{2}\left(\mathrm{CH}_{3} \mathrm{COO}\right)_{2} \cdot 2 \mathrm{H}_{2} \mathrm{O}$, tri-n-butylphosphine $\left(\mathrm{PBu}_{3}\right)$, chloroform $\left(\mathrm{CHCl}_{3}\right)$, methanol, $\mathrm{CDCl}_{3}$ for ${ }^{1} \mathrm{H} \mathrm{NMR}$ spectroscopy, acetonitrile $\left(\mathrm{CH}_{3} \mathrm{CN}\right)$, potassium bromide $(\mathrm{KBr})$ for IR spectroscopy, were purchased from Merck, Acros and Aldrich.

The electronic absorption spectra were recorded using a Perkin-Elmer Lambda 2 spectrophotometer equipped with a Lauda-ecoline-RE 104 thermostat. FTIR spectra were recorded by Shimadzu FTIR-8300 infrared spectrophotometer. The ${ }^{1} \mathrm{HNMR}$ spectra were recorded on a Bruker Avance DPX-250 spectrometer in $\mathrm{CDCl}_{3}$ solvent at $250 \mathrm{MHz}$. Elemental microanalyses (C.H.N) were obtained using a C.H.N Thermo-Finnigan Flash EA1112. BUCHI 535 instrument was used to obtain the melting point of the compounds. Thermal gravimetric analyses were recorded on Perkin-Elmer Pyris Diamond model. Electrochemistry studies were obtained using Auto lab 302N. A three-electrode system was utilized, i.e., a glassy carbon working electrode, a reference electrode $\left(\mathrm{Ag} / \mathrm{Ag}^{+}\right.$in $\mathrm{TBAP} /$ acetonitrile solution), and a $\mathrm{Pt}$ auxiliary electrode. The measurements of $\mathrm{CV}$ for $\mathrm{CH}_{3} \mathrm{CN}$ solution containing uranyl complexes $\left(1.00 \times 10^{-3} \mathrm{M}, \mathrm{M}=\mathrm{mol} / \mathrm{dm}^{3}\right)$ and TBAP $(0.10 \mathrm{M})$ were carried out in the potential range from $0.2 \mathrm{~V}$ to $-1.4 \mathrm{~V}$. Tetrabutylammoniumperchlorate (TBAP) was used as supporting electrolyte.

\subsection{Synthesis of the ligand}

Schiff bases were synthesized by the condensation of 2-aminobenzylamine (1 mmol) with substituted salicylaldehyde $(2 \mathrm{mmol})$ in methanol. The purity of the ligands was checked by thin layer chromatography (TLC) technique. The solution was refluxed for 6-7 h (scheme S1). The Schiff base ligand was precipitated and washed with small amounts of cold methanol and diethylether.

$\mathrm{N}, \mathrm{N}^{\prime}$-bis(5-methoxysalicylidene)-2-aminobenzylamine (5-MeOsalbzH $\mathrm{H}_{2}$ ): Yield: 82\%, Colour: orange, M.p. = $116^{\circ} \mathrm{C}$, Anal. Found(Calcd.): $\mathrm{C}_{23} \mathrm{H}_{22} \mathrm{~N}_{2} \mathrm{O}_{4}(390.44)$ : C, 70.66(70.75); H, 4.62(5.68); N, 7.20(7.17). FT-IR $\left(\mathrm{KBr}, \mathrm{cm}^{-1}\right): \quad 3480\left(v_{\mathrm{O}-\mathrm{H}}\right), \quad 2900-2592\left(v_{\mathrm{C}-\mathrm{H}}\right), 1627$ $\left(v_{\mathrm{C}=\mathrm{N}}\right), 1566\left(v_{\mathrm{C}=\mathrm{C}}\right) .{ }^{1} \mathrm{H}$ NMR $\left(250 \mathrm{MHz}, \mathrm{CDCl}_{3}\right)$ :

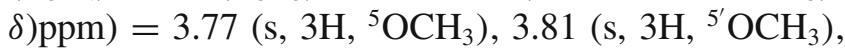
$4.94\left(\mathrm{~s}, 2 \mathrm{H}, \mathrm{CH}_{2}\right), 6.67-7.41(\mathrm{~m}, 10 \mathrm{H}, \mathrm{ArH}), 8.41$ $\left(\mathrm{s}, \quad 1 \mathrm{H},{ }^{(\mathrm{a})} \mathrm{HC}=\mathrm{N}\right), 8.51 \quad\left(\mathrm{~s}, \quad 1 \mathrm{H},{ }^{(b)} \mathrm{HC}=\mathrm{N}\right), 12.68$ $\left(\mathrm{s}, 1 \mathrm{H}, \mathrm{OH}^{(\mathrm{a})}\right), 12.85\left(\mathrm{~s}, 1 \mathrm{H}, \mathrm{OH}^{(\mathrm{b})}\right)$. UV-Vis. (acetonitrile): $\lambda_{\max }(\mathrm{nm}), \varepsilon\left(\mathrm{M}^{-1} \mathrm{~cm}^{-1}\right)=230(\sim 72822), 257(\mathrm{sh})$, 356( 22671).

N,N'-bis(4-methoxysalicylidene)-2-aminobenzylamine (4-MeOsalbzH $\mathrm{M}_{2}$ ): Yield: 66\%, Colour: yellow, M.p. = $79^{\circ} \mathrm{C}$, Anal. Found(Calcd.): $\mathrm{C}_{23} \mathrm{H}_{22} \mathrm{~N}_{2} \mathrm{O}_{4}(390.44)$ : C, 70.64(70.75); H, 5.60(5.68); N, 7.21(7.17). FT-IR $\left(\mathrm{KBr}, \mathrm{cm}^{-1}\right): 3417\left(v_{\mathrm{O}-\mathrm{H}}\right), 2839\left(v_{\mathrm{C}-\mathrm{H}}\right), 1620,1648\left(v_{\mathrm{C}=\mathrm{N}}\right)$, $\left.\left.1573-1519\left(v_{\mathrm{C}=\mathrm{C}}\right) .{ }^{1} \mathrm{H} \mathrm{NMR}\left(250 \mathrm{MHz}, \mathrm{CDCl}_{3}\right): \delta\right) \mathrm{ppm}\right)$ $=3.76\left(\mathrm{~s}, 3 \mathrm{H},{ }^{4} \mathrm{OCH}_{3}\right), 3.81\left(\mathrm{~s}, 3 \mathrm{H},{ }^{4} \mathrm{OCH}_{3}\right), 4.87$ (s, 2H, $\left.\mathrm{CH}_{2}\right), 6.33-6.53(\mathrm{~m}, 4 \mathrm{H}, \mathrm{ArH}), 7.04-7.38$ $(\mathrm{m}, 6 \mathrm{H}, \operatorname{ArH}), 8.30\left(\mathrm{~s}, 1 \mathrm{H},{ }^{(\mathrm{a})} \mathrm{HC}=\mathrm{N}\right), 8.48(\mathrm{~s}, 1 \mathrm{H}$, $\left.{ }^{(b)} \mathrm{HC}=\mathrm{N}\right), 13.58$ (s, 2H, OH). UV-Vis. (acetonitrile): $\lambda_{\max }(\mathrm{nm}), \varepsilon\left(\mathrm{M}^{-1} \mathrm{~cm}^{-1}\right)=211(\sim 61471), 257(\sim 42857)$, 309( 38148).

$\mathrm{N}, \mathrm{N}^{\prime}$-bis(3-methoxysalicylidene)-2-aminobenzylamine (3-MeOsalbzH $\mathrm{H}_{2}$ ): Yield: 66\%, Colour: orange, M.p. $=102^{\circ} \mathrm{C}$, Anal. Found(Calcd.): $\mathrm{C}_{23} \mathrm{H}_{22} \mathrm{~N}_{2} \mathrm{O}_{4}(390.44)$ : C, 70.61(70.75); H, 5.44(5.68); N, 7.15(7.17). FTIR $\left(\mathrm{KBr}, \mathrm{cm}^{-1}\right): \quad 3440\left(v_{\mathrm{O}-\mathrm{H}}\right), \quad 3031-2885 \quad\left(v_{\mathrm{C}-\mathrm{H}}\right)$, 1640 $\left(v_{\mathrm{C}=\mathrm{N}}\right), 1496\left(v_{\mathrm{C}=\mathrm{C}}\right),{ }^{1} \mathrm{H}$ NMR $(250 \mathrm{MHz}$, $\left.\left.\left.\mathrm{CDCl}_{3}\right): \delta\right) \mathrm{ppm}\right)=3.88\left(\mathrm{~s}, 3 \mathrm{H},{ }^{3} \mathrm{OCH}_{3}\right), 3.94(\mathrm{~s}, 3 \mathrm{H}$, $\left.{ }^{\prime} \mathrm{OCH}_{3}\right), 4.99\left(\mathrm{~s}, 2 \mathrm{H}, \mathrm{CH}_{2}\right), 6.78-7.44(\mathrm{~m}, 10 \mathrm{H}, \mathrm{ArH})$, $8.46\left(\mathrm{~s}, 1 \mathrm{H},{ }^{(\mathrm{a})} \mathrm{HC}=\mathrm{N}\right), 8.60\left(\mathrm{~s}, 1 \mathrm{H},{ }^{(\mathrm{b})} \mathrm{HC}=\mathrm{N}\right), 13.70$ $\left(\mathrm{s}, 1 \mathrm{H}, \mathrm{OH}^{(\mathrm{a})}\right), 13.87\left(\mathrm{~s}, 1 \mathrm{H}, \mathrm{OH}^{(\mathrm{b})}\right)$. UV-Vis. (acetonitrile): $\lambda_{\max }(\mathrm{nm}), \varepsilon\left(\mathrm{M}^{-1} \mathrm{~cm}^{-1}\right)=220(\sim 106986)$, 264( 53656), 316( 32222).

\subsection{Synthesis of the uranyl complexes}

$\mathrm{UO}_{2}\left(\mathrm{CH}_{3} \mathrm{COO}\right)_{2} 2 \mathrm{H}_{2} \mathrm{O}(1 \mathrm{mmol})$ dissolved in methanol $(15 \mathrm{~mL})$ was added gradually with constant stirring to a solution of the ligand $(1 \mathrm{mmol})$ in methanol $(15 \mathrm{~mL})$. The solution was refluxed for 6-7 h (scheme S2). The complexes were stable at room temperature.

[UO $\left.{ }_{2}(5-\mathrm{MeOsalbz})(\mathrm{MeOH})\right]$ : Yield: $90 \%$, Colour: red, M.p. $>250^{\circ} \mathrm{C}$, Anal. Found (Calcd.): $\mathrm{C}_{24} \mathrm{H}_{24} \mathrm{~N}_{2} \mathrm{O}_{7} \mathrm{U}$ (690.49): C, 41.93(41.75); H, 2.63(2.50); N, 4.09(4.06). 
FT-IR $\left(\mathrm{KBr}, \mathrm{cm}^{-1}\right): 3263\left(v_{\mathrm{O}-\mathrm{H}}\right), 2923-2831\left(v_{\mathrm{C}-\mathrm{H}}\right)$, $1620\left(v_{\mathrm{C}=\mathrm{N}}\right), \quad 1542-1473 \quad\left(v_{\mathrm{C}=\mathrm{C}}\right), 902 \quad\left(v_{\mathrm{U}=\mathrm{O}}\right), 810$ $\left(v_{\mathrm{U}-\mathrm{N}}\right), 748\left(v_{\mathrm{U}-\mathrm{O}}\right) .{ }^{1} \mathrm{H}$ NMR $\left(250 \mathrm{MHz}, \mathrm{CDCl}_{3}\right)$ : $\delta(\mathrm{ppm})=3.14(\mathrm{~d}, 3 \mathrm{H}, \mathrm{MeOH}), 3.72\left(\mathrm{~s}, 6 \mathrm{H},{ }^{5,5^{\prime}} \mathrm{OCH}_{3}\right)$, 4.09 (q, 1H, $\mathrm{MeOH}), 5.30\left(\mathrm{~s}, 2 \mathrm{H}, \mathrm{CH}_{2}\right), 6.80$ $7.68(\mathrm{~m}, 10 \mathrm{H}, \operatorname{ArH}), 9.22\left(\mathrm{~s}, 1 \mathrm{H},{ }^{(\mathrm{a})} \mathrm{HC}=\mathrm{N}\right), 9.52$ (s, $\left.1 \mathrm{H},{ }^{(\mathrm{b})} \mathrm{HC}=\mathrm{N}\right) . \quad \mathrm{UV}-$ Vis. (acetonitrile): $\lambda_{\max }(\mathrm{nm})$, $\varepsilon\left(\mathrm{M}^{-1} \mathrm{~cm}^{-1}\right)=237(\sim 51079), 296(\mathrm{sh}), 374(\sim 10043)$, 423(sh).

$\left[\mathrm{UO}_{2}(4-\mathrm{MeOsalbz})(\mathrm{MeOH})\right]$ : Yield: $90 \%$, Colour: orange, M.p. $>250^{\circ} \mathrm{C}$, Anal. Found (Calcd.): $\mathrm{C}_{24} \mathrm{H}_{24} \mathrm{~N}_{2} \mathrm{O}_{7} \mathrm{U}$ (690.49): C, 41.61(41.75); H, 3.60(3.50); N, 4.08(4.06). FT-IR $\left(\mathrm{KBr}, \mathrm{cm}^{-1}\right)$ : $3417\left(v_{\mathrm{O}-\mathrm{H}}\right), \quad 2939\left(v_{\mathrm{C}-\mathrm{H}}\right), \quad 1604\left(v_{\mathrm{C}=\mathrm{N}}\right), \quad 1535\left(v_{\mathrm{C}=\mathrm{C}}\right)$, 910 $\left(v_{\mathrm{U}=\mathrm{O}}\right), 763\left(v_{\mathrm{U}-\mathrm{N}}\right), 601\left(v_{\mathrm{U}-\mathrm{O}}\right) .{ }^{1} \mathrm{H}$ NMR $(250$ $\left.\mathrm{MHz}, \mathrm{CDCl}_{3},\right): \delta(\mathrm{ppm})=3.14(\mathrm{~d}, 3 \mathrm{H}, \mathrm{MeOH}), 3.80$ $\left(\mathrm{s}, 3 \mathrm{H},{ }^{4} \mathrm{OCH}_{3}\right), 3.85\left(\mathrm{~s}, 3 \mathrm{H},{ }^{4} \mathrm{OCH}_{3}\right) 4.07$ (q, $1 \mathrm{H}$, $\mathrm{MeOH}), 5.25$ (s, 2H, $\left.\mathrm{CH}_{2}\right), 6.27-6.54(\mathrm{~m}, 4 \mathrm{H}, \mathrm{ArH})$, 7.15-7.69 (m, 6H, ArH), $9.16\left(\mathrm{~s}, 1 \mathrm{H},{ }^{\left({ }^{a}\right)} \mathrm{HC}=\mathrm{N}\right)$, $9.47 \quad\left(\mathrm{~s}, \quad 1 \mathrm{H}, \quad{ }^{(\mathrm{b})} \mathrm{HC}=\mathrm{N}\right) . \quad \mathrm{UV}-\mathrm{Vis} . \quad$ (acetonitrile): $\lambda_{\max }(\mathrm{nm}), \varepsilon\left(\mathrm{M}^{-1} \mathrm{~cm}^{-1}\right)=224(\sim 44116), 245(49669)$, 281( 30583), 323( 27763).

[UO $\left.\mathrm{UO}_{2}(3-\mathrm{MeOsalbz})(\mathrm{MeOH})\right]$ : Yield: $81 \%$, Colour: Red, M.p. $>250^{\circ} \mathrm{C}$, Anal. Found(Calcd.): $\mathrm{C}_{24} \mathrm{H}_{24} \mathrm{~N}_{2} \mathrm{O}_{7} \mathrm{U}$ (690.49): C, 41.88(41.75); H, 3.43(3.50); N, 4.10(4.06). FT-IR $\left(\mathrm{KBr}, \mathrm{cm}^{-1}\right)$ : 3517( $\left(v_{\mathrm{O}-\mathrm{H}}\right), \quad 2939-2823\left(v_{\mathrm{C}-\mathrm{H}}\right)$, $1604\left(v_{\mathrm{C}=\mathrm{N}}\right), 1550-1442\left(v_{\mathrm{C}=\mathrm{C}}\right), 902\left(v_{\mathrm{U}=\mathrm{O}}\right), 740\left(v_{\mathrm{U}-\mathrm{N}}\right)$, $540\left(v_{\mathrm{U}-\mathrm{O}}\right) .{ }^{1} \mathrm{H}$ NMR $\left(250 \mathrm{MHz}, \mathrm{CDCl}_{3}\right): \delta(\mathrm{ppm})=$ $3.14(\mathrm{~d}, 3 \mathrm{H}, \mathrm{MeOH}), 3.90\left(\mathrm{~s}, 3 \mathrm{H},{ }^{3} \mathrm{OCH}_{3}\right), 3.96(\mathrm{~s}$, $\left.3 \mathrm{H},{ }^{3} \mathrm{OCH}_{3}\right), 4.13(\mathrm{q}, 1 \mathrm{H}, \mathrm{MeOH}), 5.31\left(\mathrm{~s}, 2 \mathrm{H}, \mathrm{CH}_{2}\right)$, 6.53-6.64 (m, 2H, ArH) , 7.15-7.71 (m, 8H, ArH), $9.23\left(\mathrm{~s}, 1 \mathrm{H},{ }^{\left({ }^{a}\right)} \mathrm{HC}=\mathrm{N}\right), 9.53\left(\mathrm{~s}, 1 \mathrm{H},{ }^{(\mathrm{b})} \mathrm{HC}=\mathrm{N}\right) . \mathrm{UV}-\mathrm{Vis}$. (acetonitrile): $\lambda_{\max }(\mathrm{nm}), \varepsilon\left(\mathrm{M}^{-1} \mathrm{~cm}^{-1}\right)=234$ ( 80829), 270( 34737), 338(sh).

\subsection{Kinetic studies of the exchange reactions}

The kinetics of the exchange reaction on the uranyl centre was studied spectrophotometrically. In all cases (runs from $10.0-40.0 \pm 0.1^{\circ} \mathrm{C}$ ), the procedure involves adding a sample of $\mathrm{PBu}_{3}$ under pseudo first order condition to a solution containing the uranyl complex. The kinetics was followed at a predetermined wavelength, where the difference in absorption between the substrate and the product was the largest. After each injection, absorbance was read in definite time intervals.

\subsection{Synthesis of the kinetic product}

To a refluxing solution of complexes $(0.1 \mathrm{~g})$ in acetonitrile $(25 \mathrm{~mL})$ was added tri-n-butylphosphine $(0.042 \mathrm{~mL})$ (1:1 molar ratio). The reaction mixture was refluxed for $24 \mathrm{~h}$ under nitrogen atmosphere. The resulting oil was grinded with n-hexane to extract impurities, and at last a powdery product was obtained.

2.5a $\left[\mathrm{UO}_{2}(5-\mathrm{MeOsalbz})\left(\mathrm{PBu}_{3}\right)\right] \cdot \mathrm{H}_{2} \mathrm{O}:$ Yield: $87 \%$, Colour: orange, M.p. $<150^{\circ} \mathrm{C}$. FT-IR $\left(\mathrm{KBr}, \mathrm{cm}^{-1}\right)$ : 2923-2831 $\left(v_{\mathrm{C}-\mathrm{H}}\right), 1620\left(v_{\mathrm{C}=\mathrm{N}}\right), 1542-1473\left(v_{\mathrm{C}=\mathrm{C}}\right)$, $902\left(v_{\mathrm{U}=\mathrm{O}}\right), 810\left(v_{\mathrm{U}-\mathrm{N}}\right), 748\left(v_{\mathrm{U}-\mathrm{O}}\right){ }^{1} \mathrm{H}$ NMR $(250$ $\mathrm{MHz}, \mathrm{DMSO}-d_{6}$, room temperature $): \delta(\mathrm{ppm})=0.82$ (t, 9H, $\left.\mathrm{CH}_{3}\right), 1.33\left(\mathrm{~m}, 12 \mathrm{H}, \mathrm{CH}_{2}\right), 1.61\left(\mathrm{t}, 6 \mathrm{H}, \mathrm{CH}_{2}\right)$, $3.82\left(\mathrm{~s}, 6 \mathrm{H},{ }^{5,5^{\prime}} \mathrm{OCH}_{3}\right), 5.35\left(\mathrm{~s}, 2 \mathrm{H}, \mathrm{CH}_{2}\right), 6.80-7.68$ $(\mathrm{m}, 10 \mathrm{H}, \operatorname{ArH}), 9.34\left(\mathrm{~s}, 1 \mathrm{H},{ }^{(\mathrm{a})} \mathrm{HC}=\mathrm{N}\right), 9.62(\mathrm{~s}, 1 \mathrm{H}$, ${ }^{(b)} \mathrm{HC}=\mathrm{N}$ ).

\subsection{Growth of the crystals for X-ray crystallography}

Red triangular single crystals of the uranyl complexes were obtained in good yield from slow diffusion of diethyl ether into a solution of the metal complex in dimethylformamide (DMF) at room temperature during 10 days. The crystals were intensely coloured.

\section{Results and Discussion}

\subsection{General information}

A range of solvent adducts of uranyl complexes of the Schiff base ligands: salen (N,N'-ethylenebis(salicylideneimine)) and salpn (N,N'-propylenebis(salicylideneimine)) have been synthesized and characterized by $\mathrm{X}$-ray crystallography. Evans et $a^{23}$ revealed the special solvent which was used in the synthesis or recrystallization was coordinated with the uranium centre.

\subsection{Characterization of the complexes}

3.2a Crystal structure determination of the complexes: The crystal structures of the complexes were characterized by means of single crystal X-ray analysis. The diffraction data were obtained using the Gemini diffractometer of Agilent Technologies, with $\mathrm{MoK} \alpha$ radiation from a sealed X-ray tube monochromated with a graphite monochromator and collimated with Mo-Enhance fibre optics collimator. The CCD Atlas was used for the detection. Data processing was done with CrysAlis Pro $^{24}$ and the same program was used for absorption correction based on the crystal shape. The structure was solved by the program Superflip ${ }^{25}$ and refined with Jana $2006 .{ }^{26}$ In case of complex 1, the structure was non-centrosymmetric, Flack parameter was also refined indicating presence of a pure 
enantiomer. The complex 2 was twinned with significant presence of overlapped reflections. These overlaps caused slight distortions in the structure, resulting in significant residual electron density located on uranium atom. The refined occupancy ratio of the twin domains was 525:475. Crystallographic data and details of the data collection are listed in table 1 . The ORTEP view of the complexes is shown in figure 2, with selected geometric parameters listed in table 2 .

The ligand is bound to the uranium centre in a tetradentate fashion in the equatorial plane of the uranyl ion. The solvent molecule occupies the fifth coordination site in the equator. Thus the coordination of uranium is a distorted pentagonal bipyramid with the 2-aza and 2-oxo sites belonging to the ligand and perpendicular to the '-yl' oxygens.

The uranyl oxygen distance U-O6 in 1 (1.784(3) A) is slightly shorter than the corresponding distances observed U-O2 in $2(1.789(6) \AA)$. This trend is almost reverse for $\mathrm{U}-\mathrm{O} 7$ in $1(1.776(3) \AA), \mathrm{U}-\mathrm{O} 4$ in 2 (1.774(6) $\AA$ ). These distances are typical for the corresponding distances reported for the other uranyl Schiff base complexes. ${ }^{10,27}$

The structures of the Schiff bases were asymmetric. Thus it is reasonable that one of the U-N distances is longer than the other. This must be true also for $\mathrm{U}-\mathrm{O}_{\text {Schiffbase }}$ distances in all the complexes. The uranyl nitrogen distance U-N3 in 1 (2.619(3) $\mathrm{A})$ is longer than
U-N2 in $1(2.590(3) \AA)$ this trend is the same in 2

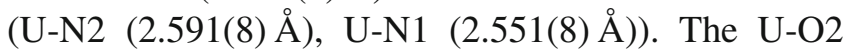
and U1-O4 bond distances for example in 1; 2.258(3) and 2.234(3) $\AA$, respectively, are shorter than U1-N2 and U1-N3 [2.590(3), 2.619(3) A]. Such a difference implies that the coordination of the oxygen atoms in the complex is stronger than the coordination of the nitrogen atoms. A DMF molecule is coordinated to the uranium, which is the solvent component in the recrystallization. The U-O1 distance in $1(2.414(3)) \AA$ and U-O3 distance in $2(2.436(5) \AA)$ are comparable to $\mathrm{U}-\mathrm{O}_{\text {solvent }}$ distance reported for the other uranyl complexes. ${ }^{10,27}$

Overall, the bond distance between the oxygen atom of DMF and uranium is longer than those of $\mathrm{U}-\mathrm{O}_{\text {Schiffbase }}$ in all complexes. This suggests that the coordination of DMF is not as strong as the coordination of the Schiff base.

The $\mathrm{O}=\mathrm{U}=\mathrm{O}$ angles in $1\left(175.9(1)^{\circ}\right)$ and 2 $\left(175.3(3)^{\circ}\right)$ indicate that the uranyl moiety is slightly bent. These angles also indicate that the uranyl moiety is slightly bent in the direction opposite to the coordination of DMF. The deviation from linearity is due to the presence of coordinated solvent. In all the complexes, the phenyl groups are present on the opposite side of the $\mathrm{UO}_{2}$ plane.

The coordination geometry around $\mathrm{UO}_{2}$ is nearly planar with the dihedral angle of 9.82(15) between coordination planes of N2-U1-O2 and N3-U1-O4 in 1

Table 1. Crystal data, data collection and structure refinement details for $\left[\mathrm{UO}_{2}(3-\right.$ MeOsalbz)(DMF)], [UO $\left.{ }_{2}(4-\mathrm{MeOsalbz})(\mathrm{DMF})\right]$.

\begin{tabular}{lrr}
\hline & {$\left[\mathrm{UO}_{2}(3-\mathrm{MeOsalbz})(\mathrm{DMF})\right]$} & {$\left[\mathrm{UO}_{2}(4-\mathrm{MeOsalbz})(\mathrm{DMF})\right]$} \\
\hline Formula & $\mathrm{C}_{26} \mathrm{H}_{27} \mathrm{~N}_{3} \mathrm{O}_{7} \mathrm{U}$ & $\mathrm{C}_{29} \mathrm{H}_{34} \mathrm{~N}_{4} \mathrm{O}_{8} \mathrm{U}$ \\
Formula weight & 731.54 & 731.54 \\
Crystal system & Orthorhombic & triclinic \\
Hall group & $P 2 a c 2 a b$ & $-P 1$ \\
Space group & $P 212121$ & $P-1$ \\
$T(\mathrm{~K})$ & $120 \mathrm{~K}$ & $120 \mathrm{~K}$ \\
$a[\AA]$ & $11.6667(1)$ & $6.9160(3)$ \\
$b[\AA]$ & $13.7492(1)$ & $13.8626(13)$ \\
$c[\AA]$ & $15.7939(3)$ & $17.0223(17)$ \\
$\alpha\left[^{\circ}\right]$ & 90 & $67.150(9)$ \\
$\beta\left[^{\circ}\right]$ & 90 & $89.287(6)$ \\
$\gamma\left[^{\circ}\right]$ & 90 & $83.821(6)$ \\
$\mathrm{V}\left[\AA^{3}\right]$ & 2533.46 & $1494.4(1)$ \\
$Z$ & 4 & 2 \\
$D_{\text {calcd. }}\left[\mathrm{Mg} \mathrm{m}{ }^{-3}\right]$ & 1.9179 & 1.7878 \\
$F(000)$ & 1408.0 & 784.0 \\
Nref & $3889[6971]$ & $5350[10255]$ \\
$T_{\min }, T_{\max }$ & $0.377,0.467$ & $0.494,0.664$ \\
$\mathrm{R}(\mathrm{reflections})$ & $0.0232(5074)$ & $0.0654(8886)$ \\
$\mathrm{wR} 2($ reflections $)$ & $0.0481(6316)$ & $0.1505(10255)$ \\
$\Delta \rho_{\max }\left(\mathrm{e} \AA^{-3}\right), \Delta \rho_{\min }\left(\mathrm{e} \AA^{-3}\right)$ & $1.17,-1.00$ & $5.04,-2.08$ \\
\hline
\end{tabular}




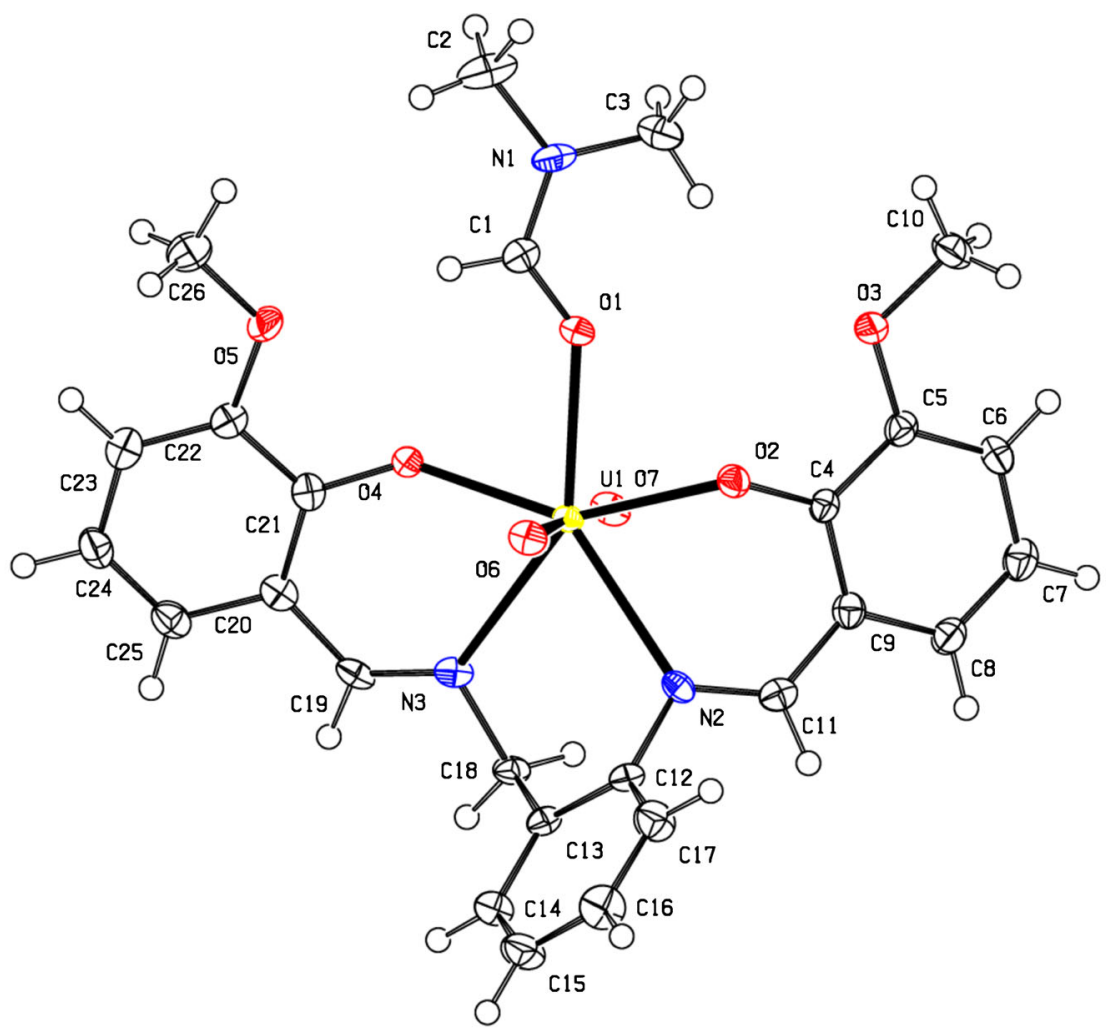

(1)

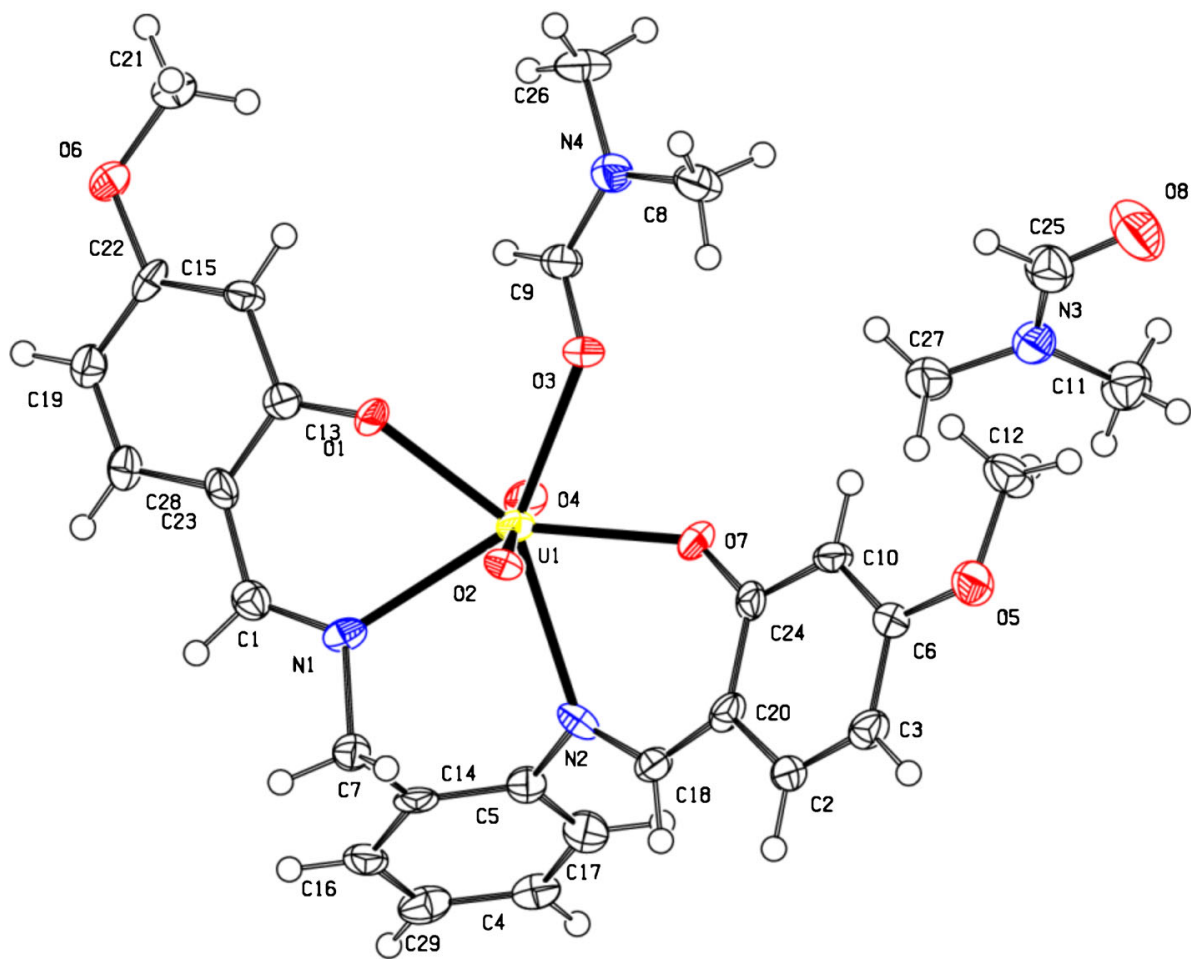

(2)

Figure 2. ORTEP view of $\left[\mathrm{UO}_{2}(3-\mathrm{MeOsalbz})(\mathrm{DMF})\right](1)$ and $\left[\mathrm{UO}_{2}(4-\mathrm{MeO}\right.$ salbz)(DMF) $](2)$ complexes. 


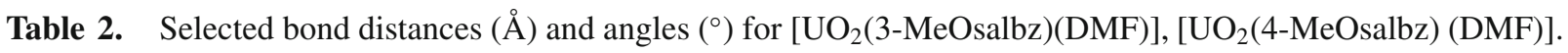

\begin{tabular}{|c|c|c|c|c|c|c|c|}
\hline \multicolumn{4}{|c|}{$\left[\mathrm{UO}_{2}(4-\mathrm{MeOsalbz})(\mathrm{DMF})\right]$} & \multicolumn{4}{|c|}{$\left[\mathrm{UO}_{2}(3-\mathrm{MeOsalbz})(\mathrm{DMF})\right]$} \\
\hline$\overline{\mathrm{U}(1)-\mathrm{O}(1)}$ & $2.414(3)$ & $\mathrm{O}(1)-\mathrm{U}(1)-\mathrm{O}(6)$ & $93.0(1)$ & $\overline{\mathrm{U}(1)-\mathrm{O}(1)}$ & $2.255(7)$ & $\mathrm{O}(2)-\mathrm{U}(1)-\mathrm{O}(4)$ & $175.3(2)$ \\
\hline $\mathrm{U}(1)-\mathrm{O}(2)$ & $2.258(3)$ & $\mathrm{O}(4)-\mathrm{U}(1)-\mathrm{N}(3)$ & $69.6(1)$ & $\mathrm{U}(1)-\mathrm{O}(2)$ & $1.789(6)$ & $\mathrm{O}(1)-\mathrm{U}(1)-\mathrm{N}(2)$ & $145.0(2)$ \\
\hline $\mathrm{U}(1)-\mathrm{O}(4)$ & $2.234(3)$ & $\mathrm{O}(1)-\mathrm{U}(1)-\mathrm{N}(2)$ & $68.5(1)$ & $\mathrm{U}(1)-\mathrm{O}(3)$ & $2.435(5)$ & $\mathrm{O}(1)-\mathrm{U}(1)-\mathrm{N}(1)$ & $70.7(2)$ \\
\hline $\mathrm{U}(1)-\mathrm{O}(6)$ & $1.784(3)$ & $\mathrm{O}(6)-\mathrm{U}(1)-\mathrm{O}(7)$ & $175.9(1)$ & $\mathrm{U}(1)-\mathrm{O}(4)$ & $1.774(6)$ & $\mathrm{O}(1)-\mathrm{U}(1)-\mathrm{O}(7)$ & $146.3(2)$ \\
\hline $\mathrm{U}(1)-\mathrm{O}(7)$ & $1.776(3)$ & $\mathrm{O}(1)-\mathrm{U}(1)-\mathrm{O}(2)$ & $73.4(1)$ & $\mathrm{U}(1)-\mathrm{O}(7)$ & $2.268(8)$ & $\mathrm{O}(1)-\mathrm{U}(1)-\mathrm{O}(3)$ & $73.7(2)$ \\
\hline $\mathrm{U}(1)-\mathrm{N}(2)$ & $2.590(3)$ & $\mathrm{O}(1)-\mathrm{U}(1)-\mathrm{O}(4)$ & $75.3(1)$ & $\mathrm{U}(1)-\mathrm{N}(1)$ & $2.551(8)$ & $\mathrm{O}(3)-\mathrm{U}(1)-\mathrm{O}(7)$ & $72.7(2)$ \\
\hline $\mathrm{U}(1)-\mathrm{N}(3)$ & $2.619(3)$ & $\mathrm{N}(1)-\mathrm{U}(1)-\mathrm{N}(3)$ & $73.8(1)$ & $\mathrm{U}(1)-\mathrm{N}(2)$ & $2.590(8)$ & $\mathrm{N}(1)-\mathrm{U}(1)-\mathrm{N}(2)$ & $74.3(3)$ \\
\hline
\end{tabular}

and the dihedral angle of 2.56(16) between coordination planes of N1-U1-O1 and N2-U1-O7 in 2.

\section{$3.3 \quad$ FT-IR spectra}

Vibrational bands in the region $3417-3480 \mathrm{~cm}^{-1}$ for the ligands are assigned to the vibrations of $\mathrm{O}-\mathrm{H}$ groups. These bands are disappeared due to the coordination of oxygens of the Schiff base to uranium. ${ }^{28-30}$ In the FTIR spectra of complexes because of the coordination of methanol to the uranyl, $\mathrm{OH}$ vibrational peaks have been seen. The weak bands at nearly $2590-3031 \mathrm{~cm}^{-1}$ are assigned to $\mathrm{C}-\mathrm{H}$ stretching vibrations. Strong bands at $1604-1648 \mathrm{~cm}^{-1}$, are assigned to azomethine group. The $\mathrm{C}=\mathrm{N}$ stretching of the complexes is generally seen in lower frequencies, indicating a decrease in the $\mathrm{C}=\mathrm{N}$ bond order because of the complexation ${ }^{28,29}$ bands below $800 \mathrm{~cm}^{-1}$ associated to U-O and U-N that confirmed the complexation of ligands to the uranyl. All the complexes exhibited medium-intensity bands at $540-748 \mathrm{~cm}^{-1}$ assignable to (U-O) bond and at 740$810 \mathrm{~cm}^{-1}$ assignable to $(\mathrm{N}-\mathrm{U})$ band. The strong band at nearly $905 \mathrm{~cm}^{-1}$ is characteristic of linear uranyl ion $(\mathrm{O}=\mathrm{U}=\mathrm{O})$ in the complex. In the kinetic product, the bands around $2869-3050 \mathrm{~cm}^{-1}$ are stronger due to the coordination of $\mathrm{PBu}_{3}$.

\section{$3.4{ }^{1}$ H NMR spectroscopy}

Signals in the region $12.68-13.87 \mathrm{ppm}$ are related to the hydroxyl groups of the Schiff bases. Because of the unsymmetrical structure of the ligand, two $\mathrm{OH}$ groups are observed as two separate singlets. After coordination of the ligand to the metal these signals are removed. Due to the unsymmetrical ligand, two signals are recorded also for the azomethine protons. Signals of the aromatic protons resolve in the range 6.27$7.71 \mathrm{ppm}$ and $\mathrm{CH}_{2}$ protons are seen at $4.87-5.31 \mathrm{ppm}$. Two singlets at $3.72-4.87 \mathrm{ppm}$ can be assigned to the OMe groups of the Schiff bases and their separate appearance again corresponds to the different chemical environment in the ligand. The proton chemical shifts of the coordinated $\mathrm{PBu}_{3}$ in the kinetic product appear at $\delta=0.8$ to $1.6 \mathrm{ppm}$. These results are in agreement with the previous results observed for metal complexes with tributylphosphine as ligand. ${ }^{31,32}$

All ${ }^{1} \mathrm{HNMR}$ of the complexes were monitored in DMSO- $d_{6}$ solvent, thus it is reasonable that DMSO- $d_{6}$ repels methanol from the coordination sphere, and coordinates to the uranium. Peaks due to free $\mathrm{MeOH}$ are observed in the ${ }^{1} \mathrm{HNMR}$ as a quartet at about $4.12 \mathrm{ppm}$ related to $\mathrm{OH}$ and a doublet at about $3.15 \mathrm{ppm}$ related to $\mathrm{CH}_{3}$.

\subsection{UV-Vis spectra}

The electronic spectra of the ligand $\left(3-\mathrm{MeOH}_{2} \mathrm{salbz}\right)$ and its complex in acetonitrile exhibit three intense bands (figure 3 ). The first band at higher energy is attributed to $\pi \rightarrow \pi^{*}$ transition of the phenyl ring and the band at lower energy arise from $\pi \rightarrow \pi *$ transition of the azomethine chromophore. The farthest energy band is $n \rightarrow \pi^{*}$ transition involving the promotion of the lone pair electrons of nitrogen atom to the anti-bonding $\pi^{*}$ orbital. Usually $\mathrm{n} \rightarrow \pi^{*}$ transition involving nitrogen atoms occurs at lower energies.

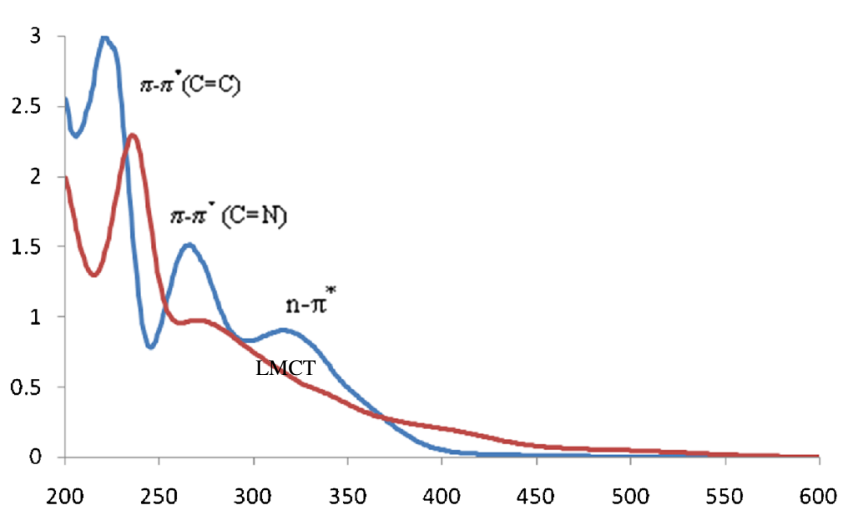

Figure 3. The electronic spectra of 3-MeOsalbz complex in acetonitrile. 
Because of the strong intensity of the characteristic absorption bands of the complexes, these absorption bands can be assigned to an electronic-dipole allowed transition arising from the coordinating ligand and/or from charge transfer between ligand and uranium atom. Owing to the presence of phenolate group these ligands can act as electron donors. Since uranyl complexes contain U(VI) with an empty valence shell, the metal centre is only capable to function as an acceptor moiety for LMCT transition. It seems that the charge transfer band $(\mathrm{LMCT})$ from oxide $(=\mathrm{O})$ to uranyl occurred at lower frequencies (higher wavelengths) than the Schiff base $^{2-} \rightarrow \mathrm{U}(\mathrm{VI}){ }^{3}$

\subsection{Thermal analysis}

In thermal analysis, the heating rates were controlled at $20^{\circ} \mathrm{C} \mathrm{min}{ }^{-1}$ under nitrogen atmosphere, and the weight loss was measured from the ambient temperature up to $1000^{\circ} \mathrm{C}$. Thermogravimetric analysis shows that uranyl complexes have very different thermal stabilities. This method is used also to establish that only one solvent molecule is coordinated to the central uranium ion and this solvent molecule does not coordinate strongly and is removed easier than the tetradentate ligand is the trans oxides. Because these complexes were synthesized in methanol, we expect that one methanol molecule is coordinated to uranium and it is confirmed by investigating the TG and TGA curves. A general decomposition pattern is concluded, whereby the complexes decomposed in two stages. The first decomposition stage is the loss of the coordinated methanol molecule, after that the delegation process started. Besides these two decomposition stages, complexes which had a lattice water, exhibited an additional decomposition step. All thermal data are collected in table S1.

\subsection{The kinetic aspects of thermal decomposition}

The well-defined stages of DTG curves were selected to study the kinetics of decomposition of the complexes. The kinetic parameters (the activation energy $E^{*}$ and the pre-exponential factor $\mathrm{A}^{*}$ ) were calculated using the Coats-Redfen equation (1): ${ }^{33}$

$\log \left[\frac{-\log (1-a)}{T^{2}}\right]=\log \frac{A R}{\beta E}\left[1-\frac{2 R T}{E}\right]-\frac{E}{2.303 R T}$

where $\mathrm{a}=\frac{\left(w_{o}-w_{t}\right)}{\left(w_{o}-w_{f}\right)}, \mathrm{w}_{0}$ initial mass of the sample, $\mathrm{w}_{\mathrm{t}}$ is mass of the sample at temperature $\mathrm{T}, \mathrm{w}_{\mathrm{f}}$ is final mass at a temperature at which the mass loss is approximately unchanged, $\beta$ is the heating rate and $\mathrm{R}$ is the gas constant. Plots of the left hand side (L.H.S.) of equation (1) against $1 / \mathrm{T}$ give a straight line, which slope and intercept and were used to calculate the kinetic parameters. The fit was checked by calculating the correlation coefficient. Other systems and their steps showed the same trend.

The entropy of activation $\mathrm{S}^{*}$ was calculated using equation (2):

$$
\mathrm{A}^{*}=\frac{K T_{s}}{h} e^{s *} / \mathrm{T}
$$

where $\mathrm{k}, \mathrm{h}$ and $\mathrm{T}_{\mathrm{s}}$ are the Boltzman constant, the Planck constant and the peak temperature, respectively. The enthalpy and free energy of activation were calculated using equations (3) and (4). ${ }^{34,35}$

$$
\begin{aligned}
\mathrm{E}^{*} & =\mathrm{H}^{*}+\mathrm{RT} \\
\mathrm{G}^{*} & =\mathrm{H}^{*}-\mathrm{TS}^{*}
\end{aligned}
$$

Kinetic parameters for all complexes are collected in table 3.

A typical linear plot of left hand side (L.H.S.) of Coats-Redforn equation vs. 1/T is shown in figure 4.

The activation energy $\left(E^{*}\right)$ in different stages is in the range of $14.68-46.57 \mathrm{~kJ} \mathrm{~mol}^{-1}$. The respective values

Table 3. Thermal and kinetic parameters for uranyl complexes.

\begin{tabular}{lcccccc}
\hline Compound & $\Delta \mathrm{T}\left({ }^{\circ} \mathrm{C}\right)^{\mathrm{a}}$ & $\mathrm{E}^{*}\left(\mathrm{kJmol}^{-1}\right)$ & $\mathrm{A}^{*}\left(\mathrm{~s}^{1}\right)$ & $\mathrm{S}^{*}\left(\mathrm{~J} \mathrm{~mol}^{-1} \mathrm{~K}^{-1}\right)$ & $\mathrm{H}^{*}\left(\mathrm{~kJ} \mathrm{~mol}^{-1}\right)$ & $\mathrm{G}^{*}\left(\mathrm{~kJ} \mathrm{~mol}^{-1}\right)$ \\
\hline$\left[\mathrm{UO}_{2}\right.$ (3-MeOsalbz)(MeOH)] & under 130 & 43.52 & 10051857 & -111.56 & 40.83 & 5.75 \\
& $150-220$ & 29.74 & 4808.04 & -178.11 & 25.88 & 34.05 \\
& $280-340$ & 22.17 & 235.16 & -204.31 & 17.42 & 60.91 \\
& $\mathrm{~T}>340$ & 46.57 & 7304.44 & -179.54 & 39.61 & 101.35 \\
{$\left[\mathrm{UO}_{2}\right.$ (4-MeOsalbz)(MeOH) $]$} & under 100 & & & & & \\
& $100-190$ & 14.85 & 115630.2 & -149.15 & 31.98 & 10.43 \\
& $260-410$ & 32.48 & 152.21 & -209.30 & 11.09 & 34.06 \\
& $\mathrm{~T}>410$ & 23.85 & 511.56 & -216.76 & 11.78 & 28.87 \\
\hline
\end{tabular}




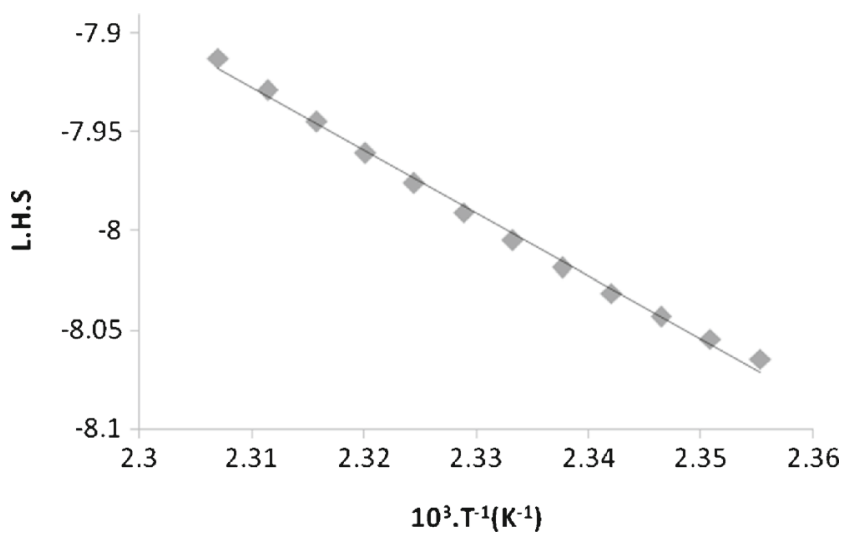

Figure 4. Coats-Redforn plot of 5-MeOsalbz complex. L.H.S. $=\log \left[\frac{-\log (1-a)}{T^{2}}\right]$.

of the pre-exponential factor $\left(\mathrm{A}^{*}\right)$ vary from $4.70 \times 10^{1}$ to $1.00 \times 10^{7} \mathrm{~s}^{-1}$. The corresponding values of the entropy of activation $\left(\mathrm{S}^{*}\right)$ are in the range of -111.56 to $-216.76 \mathrm{~J} . \mathrm{K}^{-1} \cdot \mathrm{mol}^{-1}$. The corresponding values of the enthalpy of activation $\left(\mathrm{H}^{*}\right)$ are in the range of $11.09-40.83 \mathrm{~kJ}^{-\mathrm{mol}^{-1}}$. The corresponding values of the free energy of activation $\left(\mathrm{G}^{*}\right)$ are in the range of 10.58$86.23 \mathrm{~kJ} \mathrm{~mol}^{-1}$. The negative values of entropy of activation indicate that the activated complex has a more ordered structure than the reactants. ${ }^{35,36}$ According to Coats-Redfern plots (figure 4) the kinetics of thermal decomposition of the studied complexes is of the firstorder in all stages.

\subsection{The electrochemical study of uranyl complexes}

In order to investigate the effect of substitutional groups of the Schiff base ligands on the oxidation and reduction potential, uranyl Schiff base complexes were studied by the cyclic voltammetry method. Cyclic voltammetry measurements for uranyl complex solutions in acetonitrile, including the complexes $\left[\mathrm{UO}_{2}(\mathrm{~L})\left(\mathrm{CH}_{3} \mathrm{CN}\right)\right]$ with $\mathrm{L}=3-\mathrm{MeOsalbz}$, 4-MeOsalbz, 5-MeOsalbz $(1 \times$ $10^{-3} \mathrm{M}$ ) and TBAP (tetrabutylammoniumperchlorate) $(0.10 \mathrm{M})$ as the supporting electrolyte were carried out at room temperature and in the potential range from -0.65 to $-1.35 \mathrm{~V}$ at scan rates $(\mathrm{V}=0.1 \mathrm{~V} / \mathrm{s})$. Typical cyclic voltammograms of the complexes in the potential range from -0.5 to $-1.3 \mathrm{~V}$ (vs. $\mathrm{Ag} / \mathrm{AgCl}$ ) are shown in figure 5 .

$\left[\mathrm{UO}_{2}(\mathrm{~L})\left(\mathrm{CH}_{3} \mathrm{CN}\right)\right]$ is reduced to the mono anion $\left[\mathrm{UO}_{2}(\mathrm{~L})\left(\mathrm{CH}_{3} \mathrm{CN}\right)\right]^{-}$in a quasireversible one electron step (equation 5).

$$
\begin{array}{r}
{\left[\mathrm{U}^{\mathrm{VI}} \mathrm{O}_{2}(\mathrm{~L}) \mathrm{CH}_{3} \mathrm{CN}\right]+\mathrm{e} \rightarrow\left[\mathrm{U}^{\mathrm{V}} \mathrm{O}_{2}(\mathrm{~L}) \mathrm{CH}_{3} \mathrm{CN}\right]^{-}} \\
\mathrm{L}=3-\mathrm{MeOsalbz}, 4-\mathrm{MeOsalbz}, 5-\mathrm{MeOsalbz}
\end{array}
$$

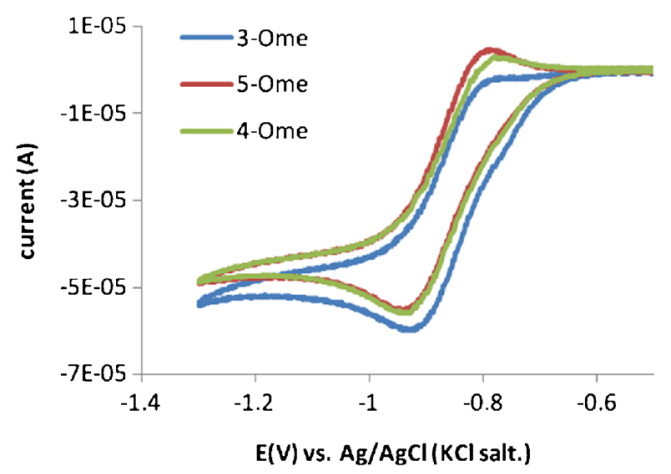

Figure 5. Cyclic voltammograms of uranyl complexes in acetonitrile at room temperature. Scan rate: $100 \mathrm{mV} / \mathrm{s}$. Scan rate: $100 \mathrm{mV} / \mathrm{s}$.

The uranium in $\mathrm{U}^{\mathrm{VI}} \mathrm{O}_{2}^{2+}$ has no $4 \mathrm{f}$ electron while that in $\mathrm{U}^{\mathrm{V}} \mathrm{O}_{2}^{+}$it has one $4 \mathrm{f}$ electron. Thus the electron density on $\mathrm{U}^{\mathrm{V}}$ atom is larger than that on $\mathrm{U}^{\mathrm{VI}}$ atom. Upon reversion of the scan direction, the $\mathrm{U}(\mathrm{V})$ complex is oxidized to $\mathrm{U}(\mathrm{VI})$ at over potentials. The redox potentials for the different complexes are collected in table 4 . The formal potentials $\left(\mathrm{E}_{1 / 2}(\mathrm{VI} \leftrightarrow \mathrm{V})\right)$ for the $\mathrm{U}(\mathrm{V} / \mathrm{VI})$ redox couple were calculated as the average of the cathodic $\left(\mathrm{E}_{\mathrm{pc}}\right)$ and anodic $\left(\mathrm{E}_{\mathrm{pa}}\right)$ peak potentials of this process. The anodic peak potentials become more negative in the order $5-\mathrm{MeO}(-0.79)>3-\mathrm{MeO}(-0.78)>4-\mathrm{MeO}$ $(-0.75)$. Methoxy group on para- $(5-\mathrm{MeO})$ and ortho(3-MeO) position is an electron releasing group, while when located on meta- (4-MeO) it acts as a weaker electron releasing group. This factor accelerates oxidation of 5-MeO and 3-MeO comparing with 4-MeO.

\subsection{Kinetic study of the exchange of solvent with $\mathrm{PBu}_{3}$ on the uranium centre}

We have also studied the kinetics of interaction between the uranyl Schiff base complexes as acceptor and $\mathrm{PBu}_{3}$ as a donor (equation 6).

$$
\begin{aligned}
& {\left[\mathrm{UO}_{2}(\mathrm{~L})\left(\mathrm{CH}_{3} \mathrm{CN}\right)\right]+\mathrm{PBu}_{3} \rightarrow\left[\mathrm{UO}_{2}(\mathrm{~L})\left(\mathrm{PBu}_{3}\right)\right]} \\
& +\mathrm{CH}_{3} \mathrm{CN} \mathrm{L}=3-\mathrm{MeOsalbz}, 4-\mathrm{MeOsalbz}, 5-\mathrm{MeO} \text { salbz }
\end{aligned}
$$

Plots of $\mathrm{k}_{\text {obs }} v s .\left[\mathrm{PBu}_{3}\right]$ exhibit a non-zero intercept. The observed intercept can be assigned to the solvation of the substrate.

The rate law for the reaction is as follows: (equations 7-9).

$$
\mathrm{R}=\left\{\mathrm{k}_{1}+\mathrm{k}_{2}\left[\mathrm{PBu}_{3}\right]\right\}[\text { complex }]
$$

under pseudo-first-order condition:

$$
\left.\mathrm{R}=\mathrm{k}_{\text {obs }} \text { [complex }\right]
$$

where: $\mathrm{k}_{\mathrm{obs}}=\mathrm{k}_{1}+\mathrm{k}_{2}\left[\mathrm{PBu}_{3}\right]$ 
Table 4. Redox potential data of uranyl Schiff base complexes in acetonitrile solution.

\begin{tabular}{lccc}
\hline Compound & $\mathrm{E}_{\mathrm{pa}}(\mathrm{V} \rightarrow \mathrm{VI})$ & $\mathrm{E}_{\mathrm{pc}}(\mathrm{VI} \rightarrow \mathrm{V})$ & $\mathrm{E}_{1 / 2}(\mathrm{VI} \leftrightarrow \mathrm{V})$ \\
\hline$\left[\mathrm{UO}_{2}(4-\mathrm{MeOsalbz})\left(\mathrm{CH}_{3} \mathrm{CN}\right)\right]$ & -0.7513 & -0.9317 & -0.8415 \\
{$\left[\mathrm{UO}_{2}(5-\mathrm{MeOsalbz})\left(\mathrm{CH}_{3} \mathrm{CN}\right)\right]$} & -0.7919 & -0.9436 & -0.8678 \\
{$\left[\mathrm{UO}_{2}(3-\mathrm{MeOsalbz})\left(\mathrm{CH}_{3} \mathrm{CN}\right)\right]$} & -0.7794 & -0.9393 & -0.8593 \\
\hline
\end{tabular}

$\mathrm{k}_{1:}$ The first order rate constant for the expelled solvent path (scheme 1, path 2).

$\mathrm{k}_{2:}$ The second order rate constant (scheme 1, path 1).

The rate constants and the activation parameters are collected in tables 5-8. Mechanism as shown in scheme 1 , is suggested for the reaction of uranyl complex with $\mathrm{PBu}_{3}$.

Two paths are suggested for the reaction. In the path one, $\mathrm{PBu}_{3}$ adds to the uranium centre by an associative mechanism with a rate constant $\mathrm{k}_{2}$, with the suggested structures shown in scheme 1 . An octa-coordinate intermediate is formed and then by repelling the solvent molecule, a hepta-coordinate product is produced again. In the path two (a dissociative path) with $\mathrm{k}_{1}$ rate constant a hexa-coordinate intermediate is formed and $\mathrm{PBu}_{3}$ coordinate to uranium centre in a fast step.

The variation of the electronic spectra for $\left[\mathrm{UO}_{2}(3-\right.$ MeOsalbz) $\left.\left(\mathrm{CH}_{3} \mathrm{CN}\right)\right]$, reacting with excess $\mathrm{PBu}_{3}$ at $10^{\circ} \mathrm{C}$ is shown in figure $\mathrm{S} 1$.

The $\mathrm{k}_{2}$ values were obtained from the slope of the linear plots of $\mathrm{k}_{\mathrm{obs}} v s$. the donor concentration [ $\left.\mathrm{PBu}_{3}\right]$ (figure S2). The activation parameters of the studied systems were calculated using Eyring equation (10):

$$
\ln \left(\mathrm{k}_{2} / \mathrm{T}\right)=-\Delta \mathrm{H}^{\#} / \mathrm{RT}+\Delta \mathrm{S}^{\#} / \mathrm{R}+23.8
$$

A typical linear Eyring plot of $\ln \left(\mathrm{k}_{2} / \mathrm{T}\right) v s .1 / \mathrm{T}$ with a good correlation of $0.97-0.99$ at four different temperatures for $\left[\mathrm{UO}_{2}(5-\mathrm{MeOsalbz})\left(\mathrm{CH}_{3} \mathrm{CN}\right)\right]$ is shown in figure S3.
The Gibbs free energy $\Delta \mathrm{G}^{\#}$ was calculated using equation (11) at $\mathrm{T}=293.15 \mathrm{~K}$.

$$
\Delta \mathrm{G}^{\#}=\Delta \mathrm{H}^{\#}-\mathrm{T} \Delta \mathrm{S}^{\#}
$$

The $k_{2}$ values for the ligands entry show high span, suggesting the dependence of the rate constant on the nature of the complex. The low $\Delta \mathrm{H}^{\#}$ values and the large negative $\Delta S^{\#}$ values are compatible with an associative (A) mechanism. For studying the effect of substitutional groups, we compared three complexes 3MeOsalbz, 4-MeOsalbz and 5-MeOsalbz with different positions of the substitutional group. Methoxy is an electron releasing group but it shows the strongest effect in para-position to the oxygen of the phenyl ring. Thus $\mathrm{k}_{2}$ values for 5-MeOsalbz are smaller than 4MeOsalbz because in the meta- position (4-MeO), electron releasing effect is weaker than para-position. If $\mathrm{MeO}$ is positioned in the ortho- position (3-MeO), the steric hindrance is more important than the electronic effect. According to the proposed mechanism, it seems that the solvent molecule in $3-\mathrm{MeO}$ complex is coordinated weaker than the other. Thus, $\mathrm{PBu}_{3}$ can interact with the complex faster than $4-\mathrm{MeO}$ and $5-\mathrm{MeO}$ complexes.

It is concluded that both electronic and steric effects are effective in the rate of exchange reaction, and the following trend is obtained: $\mathrm{UO}_{2}(3-\mathrm{MeOsalbz})>$ $\mathrm{UO}_{2}(4-\mathrm{MeOsalbz})>\mathrm{UO}_{2}(5-\mathrm{MeOsalbz})$.

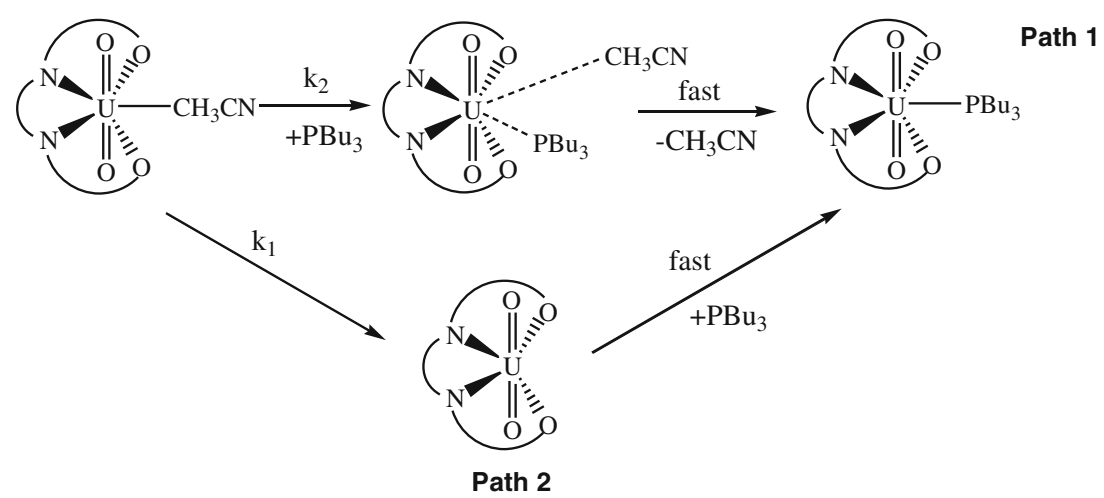

Scheme 1. The proposed paths for the kinetic study. 
Table 5. Pseudo-first-order rate constants $\mathrm{k}_{\mathrm{obs}}^{\mathrm{a}}\left(\mathrm{s}^{-1}\right), \mathrm{k}_{1}$ and $10^{2} \mathrm{k}_{2}^{\mathrm{a}}$ for the reaction of $\left[\mathrm{UO}_{2}(3-\mathrm{MeOsalbz})\left(\mathrm{CH}_{3} \mathrm{CN}\right)\right]$ with $\mathrm{PBu}_{3}$ at different temperatures.

\begin{tabular}{lccccccccc}
\hline $10^{2}[\mathrm{P}] / \mathrm{M}$ & 0.3 & 0.4 & 0.5 & 0.6 & 0.6 & 0.7 & 0.8 & $\mathrm{k}_{1} / \mathrm{s}^{-1}$ & $\mathrm{k}_{2} / \mathrm{M}^{-1} \mathrm{~s}^{-1}$ \\
\hline $10^{\circ} \mathrm{C}$ & $1.22(0.04)$ & $1.34(0.03)$ & $1.54(0.13)$ & $1.72(0.12)$ & $1.97(0.09)$ & $2.17(0.03)$ & $2.23(0.14)$ & $0.34(0.04)$ & $17.50(1.01)$ \\
$20^{\circ} \mathrm{C}$ & $1.32(0.21)$ & $1.59(0.13)$ & $1.75(0.04)$ & $2.04(0.06)$ & $2.25(0.12)$ & $2.57(0.1)$ & $2.84(0.07)$ & $1.01(0.21)$ & $24.32(0.07)$ \\
$30^{\circ} \mathrm{C}$ & $1.71(0.13)$ & $2.04(0.11)$ & $2.32(0.03)$ & $2.85(0.04)$ & $3.14(0.07)$ & $3.42(0.03)$ & $3.76(0.04)$ & $1.43(0.31)$ & $34.00(0.04)$ \\
$40^{\circ} \mathrm{C}$ & $1.85(0.21)$ & $2.27(0.02)$ & $2.71(0.05)$ & $3.16(0.15)$ & $3.56(0.04)$ & $3.84(0.15)$ & $4.31(0.08)$ & $2.31(0.41)$ & $42.04(0.05)$ \\
\hline
\end{tabular}

a) The numbers in parentheses are the standard deviations of $k$.

Table 6. Pseudo-first-order rate constants $\mathrm{k}_{\mathrm{obs}}^{\mathrm{a}}\left(\mathrm{s}^{-1}\right), \mathrm{k}_{1}$ and $10^{2} \mathrm{k}_{2}^{\mathrm{a}}$ for the reaction of $\left[\mathrm{UO}_{2}(4-\mathrm{MeOsalbz})\left(\mathrm{CH}_{3} \mathrm{CN}\right)\right]$ with $\mathrm{PBu}_{3}$ at different temperatures.

\begin{tabular}{lccccccccc}
\hline $10^{3}[\mathrm{P}] / \mathrm{M}$ & 0.1 & 0.15 & 0.2 & 0.25 & 0.3 & 0.35 & 0.4 & $\mathrm{k}_{1} / \mathrm{s}^{-1}$ & $\mathrm{k}_{2} / \mathrm{M}^{-1} \mathrm{~s}^{-1}$ \\
\hline $10^{\circ} \mathrm{C}$ & $0.32(0.04)$ & $1.12(0.01)$ & $1.91(0.02)$ & $2.73(0.15)$ & $3.32(0.06)$ & $4.21(0.08)$ & $5.24(0.07)$ & $0.49(0.00)$ & $5.13(0.07)$ \\
$20^{\circ} \mathrm{C}$ & $1.26(0.02)$ & $2.34(0.03)$ & $3.17(0.03)$ & $4.07(0.11)$ & $5.04(0.03)$ & $6.14(0.08)$ & $7.38(0.04)$ & $0.22(0.01)$ & $9.24(0.04)$ \\
$30^{\circ} \mathrm{C}$ & $2.61(0.02)$ & $3.97(0.14)$ & $5.27(0.04)$ & $6.63(0.13)$ & $7.87(0.11)$ & $9.46(0.13)$ & $11.02(0.12)$ & $0.96(0.02)$ & $13.81(0.02)$ \\
$40^{\circ} \mathrm{C}$ & $3.66(0.06)$ & $6.02(0.20)$ & $8.19(0.07)$ & $10.21(0.14)$ & $12.22(0.13)$ & $14.82(0.16)$ & $17.09(0.08)$ & $1.23(0.08)$ & $22.12(0.04)$ \\
\hline
\end{tabular}

a) The numbers in parentheses are the standard deviations of $k$.

Table 7. Pseudo-first-order rate constants $\mathrm{k}_{\mathrm{obs}}^{\mathrm{a}}\left(\mathrm{s}^{-1}\right), \mathrm{k}_{1}$ and $10^{2} \mathrm{k}_{2}^{\mathrm{a}}$ for the reaction of $\left[\mathrm{UO}_{2}(5-\mathrm{MeOsalbz})\left(\mathrm{CH}_{3} \mathrm{CN}\right)\right]$ with $\mathrm{PBu}_{3}$ at different temperatures.

\begin{tabular}{lccccccccc}
\hline $10^{2}[\mathrm{P}] / \mathrm{M}$ & 2.0 & 2.2 & 2.4 & 2.6 & 2.8 & 3.0 & 3.2 & $\mathrm{k}_{1} / \mathrm{s}^{-1}$ & $\mathrm{k}_{2} / \mathrm{M}^{-1} \mathrm{~s}^{-1}$ \\
\hline $10^{\circ} \mathrm{C}$ & $0.58(0.12)$ & $0.94(0.25)$ & $1.03(0.07)$ & $1.11(0.05)$ & $1.23(0.41)$ & $1.29(0.24)$ & $1.39(0.12)$ & $0.22(0.10)$ & $4.34(0.00)$ \\
$20^{\circ} \mathrm{C}$ & $1.11(0.38)$ & $1.20(0.31)$ & $1.29(0.22)$ & $1.38(0.05)$ & $1.50(0.11)$ & $1.62(0.22)$ & $1.73(0.41)$ & $0.31(0.00)$ & $5.41(0.02)$ \\
$30^{\circ} \mathrm{C}$ & $1.41(0.32)$ & $1.53(0.14)$ & $1.69(0.48)$ & $1.82(0.13)$ & $1.95(0.15)$ & $2.08(0.15)$ & $2.25(0.32)$ & $0.90(0.01)$ & $6.92(0.05)$ \\
$40^{\circ} \mathrm{C}$ & $1.83(0.12)$ & $2.0(0.65)$ & $2.16(0.29)$ & $2.35(0.21)$ & $2.45(0.32)$ & $2.72(0.24)$ & $2.90(0.25)$ & $0.71(0.02)$ & $8.90(0.07)$ \\
\hline
\end{tabular}

a) The numbers in parentheses are the standard deviations of $k$.

Table 8. The activation parameters $\Delta \mathrm{H}^{\# \mathrm{a}}, \Delta \mathrm{G}^{\# \mathrm{a}}$ and $\Delta \mathrm{S}^{\# \mathrm{a}}$ for the interaction of the complexes with $\mathrm{PBu}_{3}$.

\begin{tabular}{lc}
\hline Complex & $\Delta \mathrm{G}^{\mathrm{\# b} / \mathrm{kJmol}^{-1}}$ \\
\hline$\left[\mathrm{UO}_{2}(3-\mathrm{OMeSalbz})(\mathrm{MeOH})\right]$ & $55.77(2.91)^{\mathrm{a}}$ \\
{$\left[\mathrm{UO}_{2}(4-\mathrm{OMeSalbz})(\mathrm{MeOH})\right]$} & $56.32(3.21)$ \\
{$\left[\mathrm{UO}_{2}(5-\mathrm{OMeSalbz})(\mathrm{MeOH})\right]$} & $58.36(0.95)$ \\
\hline
\end{tabular}

a) The numbers in parentheses are the standard deviations. b) $\Delta \mathrm{G}^{\#}$ was calculated from $\Delta \mathrm{G}^{\#}=\Delta \mathrm{H}^{\#}-\mathrm{T} \Delta \mathrm{S}^{\#}$ at $\mathrm{T}=20^{\circ} \mathrm{C}$.

\section{Conclusion}

This study involved the synthesis of new uranyl unsymmetrical Schiff base complexes and their investigation by various methods. The X-ray structure analysis of the complexes revealed that one solvent molecule was coordinated weakly to the uranium centre. This fact was confirmed by thermal gravimetric studies and led to an idea to study kinetics and mechanism of the solvent exchange reaction with tributylphosphine in acetonitrile. High span of the second order rate constant $\left(\mathrm{k}_{2}\right)$, low $\Delta \mathrm{H}^{\#}$ and large negative $\Delta \mathrm{S}^{\#}$ values suggested an associative (A) mechanism. Both electronic and steric effects were effective and important in the rate of the exchange reaction. The trend of $\mathrm{k}_{2}$ values showed that substitutional group ( $\mathrm{MeO})$ in meta positions to the phenolic oxygen of the Schiff base accelerates the rate of the exchange reaction by attracting $\mathrm{PBu}_{3}$ as an electron donor toward uranium centre. On the other hand, $\mathrm{MeO}$ in para position of the phenolic oxygen of the Schiff base reduce the rate of the exchange reaction because of the electron deficiency of uranium centre. For the rate of the exchange reaction of the $3-\mathrm{MeO}$ complex the steric effect was the most important factor.

Cyclic voltammetry was used to investigate the effect of substitutional group of ligands on reduction and oxidation of uranium, $\mathrm{U}^{(\mathrm{VI})} \leftrightarrow \mathrm{U}^{(\mathrm{V})}$. It was concluded that the electron releasing substitutional groups accelerate oxidation of uranium. 
The properties of these complexes in solid-state were interesting too. Kinetics of thermal decomposition was investigated and kinetic parameters (the activation energy $E^{*}$ and the pre-exponential factor $A^{*}$ ) were calculated. The negative values of entropy of activation showed that the activated complex has a more ordered structure than the reactants. According to Coats-Redfern plots the kinetics of thermal decomposition of the studied complexes was of the first-order in all stages.

\section{Supplementary Information}

CCDC 914883 (3-OMe) and 949507 (4-OMe) contains the supplementary crystallographic data for this paper. These data can be obtained free of charge from The Cambridge Crystallographic Data Centre via www. ccdc.cam.ac.uk/data_request/cif.

\section{Acknowledgements}

We are grateful to Shiraz University Research Council for its financial support. The project P204/11/0809 of the Grant agency of the Czech Republic supported the crystallographic part of the work.

\section{References}

1. Vaughn A E, Bassil D B, Barnes C L, Tucker S A and Duval P B 2006 J. Am. Chem. Soc. 12810656

2. Mihalcea I, Henry N, Clavier N, Dacheux N and Loiseau T 2011 Inorg. Chem. 506243

3. Riisiö A, Väisänen A and Sillanpää R 2013 Inorg. Chem. $\mathbf{5 2} 8591$

4. Ghosh S, Biswas S, Bauzá A, Barceló-Oliver M, Frontera A and Ghosh A 2013 Inorg. Chem. 527508

5. Nocton G, Horeglad P, Vetere V, Pécaut J, Dubois L, Maldivi P, Edelstein N M and Mazzanti M 2010 J. Am. Chem. Soc. 132495

6. Brancatelli G, Pappalardo A, Sfrazzetto G T, Notti A and Geremia S 2013 Inorg. Chim. Acta 39625

7. Shen X, Liao L, Chen L, He Y, Xu C, Xiao X, Lin Y and Nie C 2014 Spectrochim. Acta Part A 123110

8. Mandal L, Bhattacharya S and Mohanta S 2013 Inorganica Chimica Acta 40687
9. Back D F, Manzoni de Oliveira G, Roman D, Ballin M A, Kober R and Piquini P C 2014 Inorg. Chim. Acta 4126

10. Takao K and Ikeda Y 2007 Inorg. Chem. 461550

11. Wu X, Bharara M S, Bray T H, Tate B K and Gorden A E V 2009 Inorganica Chim Acta 3621847

12. Bharara M S, Strawbridge K J, Vilsek Z, Bray T H and Gorden A E V 2007 Inorg. Chem. 468309

13. Takao K, Tsushima S, Takao S, Scheinost A C, Bernhard G, Ikeda Y and Hennig C 2009 Inorg. Chem. 489602

14. Mizuoka K, Tsushima S, Hasegawa M, Hoshi T and Ikeda Y 2005 Inorg. Chem. 446211

15. Takao K, Kato M, Takao S, Nagasawa A, Bernhard G, Hennig C and Ikeda Y 2010 Inorg. Chem. 492349

16. Takao K, Takahashi $\mathrm{T}$ and Ikeda $\mathrm{Y} 2009$ Inorg. Chem. 481744

17. Sessler J A, Melfi P J and Pantos G D 2006 Coor. Chem. Rev. 250816

18. Kannappan R, Tooke D M, Spek A L and Reedijk J 2006 Inorg. Chim. Acta 359334

19. Arnold P L, Blake A J, Wilson C and Love J B 2004 Inorg. Chem. $\mathbf{4 3} 8206$

20. Takao K, Kato M, Takao S, Nagasawa A, Scheinost A C, Bernhard G, Hennig C and Ikeda Y 2009 Actinides 1

21. Schettini M F, Wu G and Hayton T W 2009 Inorg. Chem. 4811799

22. Mizuoka K and Ikeda Y 2003 Inorg. Chem. 423396

23. Evans J D, Junk P C and Smith M K 2002 Polyhedron 212421

24. Agilent Technologies (2012) Crys Alis PRO. Yarnton, Oxfordshire, England

25. Palatinus L and Chapuis G 2007 J. Appl. Cryst. 40786

26. Petricek V, Dusek M and Palatinus L (2006) Jana 2006 Structure Determination Software Programs. Institute of Physics, Praha, Czech Republic

27. Costa G, Mestroni G, Tauzher G and Stefani L 1966 Organometallic Chem. 6181

28. Garg B S and Kumar D N 2003 Spectrochim. Acta Part A $\mathbf{5 9} 229$

29. Anthonysamy A and Balasubramanian S 2005 Inorg. Chem. Commun. 8908

30. Kumar D N and Garg B S 2006 Spectrochim. Acta Part A 59141

31. Asadi M and Sarvestani A H 2001 Can. J. Chem. 791360

32. Asadi M and Sarvestani A H 2002 J. Chem. Research(s) 520

33. Coats AW and Redfern J P 1964 Nature 20168

34. Aravindakshan K K and Muraleedharan K 1989 Thermochim. Acta 155247

35. Nair M K M and Radhakrishnan P K 1995 Thermochim. Acta 261141

36. Mathew S, Nair C G R and Ninan K N 1989 Thermochim. Acta 155247 